\title{
UVODNIK
}

\section{VARNOST KOT IMPERATIV}

Sodobni vojaški izzivi leta 2017 vstopajo v devetnajsto leto izhajanja, kar nas opozarja na pomembno obletnico leta 2018. Prva številka je izšla septembra 1999, in sicer kot Bilten Slovenske vojske. Od takrat do konca lanskega leta je bilo v 18 letnikih objavljenih 438 prispevkov, ki jih je napisalo 564 avtorjev. Iz Slovenske vojske je bilo 289 avtorjev, iz upravnega dela ministrstva pa 48. Drugih avtorjev iz različnih ustanov je bilo 161, iz tujine pa 66.

Letos se bomo posvetili aktualnim temam, za katere upamo, da bodo zanimive in bomo vas, bralce, $\mathrm{z}$ njimi spodbudili k razpravi, razmišljanju in morda tudi k pisanju o svojih pogledih na nastajanje nove varnosti kot imperativa za prihodnost.

Druga letošnja številka bo imela naslov Veteranske organizacije - ali jih sploh potrebujemo, izšla bo v angleškem jeziku. Te teme v zgodovini publikacije še nismo obravnavali, zato je morda tokrat pravi čas tudi zanjo in za izmenjavo izkušenj med različnimi državami.

Tudi tretja številka letošnjega letnika bo angleška, njen naslov bo Migracije in varnost na stari celini. Posvečena bo nemirnemu Bližnjemu vzhodu, terorizmu v Evropi in nacionalnim izkušnjam z migracijami, s poudarkom na migracijah od jeseni 2015 do pomladi 2016, ter evropskim odzivom nanje.

Naslov četrte številke bo Varnostne sile prihodnosti, v njej pa bo poudarek na tem, kako naprej pri zagotavljanju varnosti. Med aktualnejšimi temami bodo zagotovo novi stari načini popolnjevanja oboroženih sil, doseganje ciljev zmogljivosti sil ter mednarodne operacije in misije. Letos mineva tudi 20 let, odkar so se pripadnice in pripadniki Slovenske vojske prvič pridružili mednarodni operaciji, to je bila operacija Alba v Albaniji. Od takrat so sodelovali v številnih operacijah in na misijah po svetu. 
Leto 2017 bo nedvomno zaznamovano z ugotovitvami Strateškega pregleda obrambe 2016, in nalogami, ki iz njega izhajajo. V poglavju o krepitvi obrambne sposobnosti in odpornosti so določeni glavni cilj nadaljnjega razvoja obrambnega sistema in obrambne sposobnosti Republike Slovenije, ki izhajajo iz ugotovitev strateškega pregleda in so jih avtorji dokumenta razvrstili v zagotovitev potrebnih obrambnih zmogljivosti države, večjo odpornost države in družbe pred varnostnimi grožnjami, izboljšanje pripravljenosti in vzdržljivosti Slovenske vojske ter uresničevanje skupnih ciljev in zavez znotraj EU in Nata.

Prepričani smo, da bodo članki iz tokratne številke Sodobnih vojaških izzivov z naslovom Varnost kot imperativ lahko prispevali k ciljem, ki so zapisani v Strateškem pregledu obrambe.

Obrambo planiranje - nujen instrument politike pri zagotavljanju obrambnih potreb države je naslov članka, ki ga je napisal Pavel Vuk. V sklepnem delu ugotavlja, da bi moralo biti osrednje vprašanje politike, ko z vidika omejenih ekonomskih zmožnosti govorimo o prihodnjih obrambnih potrebah države, vselej usmerjeno v obrambno planiranje. Zanimati bi jo moral predvsem odgovor na temeljno vprašanje, ali bo predlagani načrt ponudil dovolj dobre odgovore za prihodnje nacionalne obrambne potrebe.

Nina Raduha in Pavel Vuk sta avtorja članka Krizno upravljanje na obrambnem področju, s poudarkom $v$ Slovenski vojski. V njem polemizirata in opozarjata na to, da je skrb, ki se na tem področju pojavlja, povezana s prestižno miselnostjo ključnih odločevalcev o vključevanju Slovenske vojske v kriznih razmerah, kar se kot posledica pogosto kaže v njenem prepoznem aktiviranju oziroma njenem premajhnem obsegu.

V tej številki svojo trilogijo o četrti generaciji vojskovanja končuje Viktor Potočnik. Tokratni naslov prispevka je Četrta generacija vojskovanja, 3. del: Nov koncept SV za delovanje v četrti generaciji vojskovanja. V njem se je avtor v sklepnem delu posvetil področjem izobraževanja, usposabljanja, organizacije in strukture ter popolnjevanja SV. Med njegovimi sklepnimi mislimi je tudi misel, da priprava nujnih sprememb in razmislek o njih ne zahtevata posebnih virov, zahtevata pa intenzivno komunikacijo SV s politiko in družbo, ki mora temeljiti na strokovnih podlagah.

Pojmovnim opredelitvam vojaškega izobraževanja in usposabljanja se je posvetil Vinko Vegič v članku z naslovom Temeljno šolanje častnikov v državah Evropske unije - iskanje odgovorov na sodobne zahteve. Pripravil je primerjalno analizo razumevanja med različnimi avtorji in načinom vojaškega izobraževana in usposabljanja v nekaterih državah. Bistvene so njegove ugotovitve o Sloveniji in SV. 
O organizacijskih vidikih vojaškega izobraževanja in usposabljanja piše Tomaž Kladnik v članku z naslovom Vojaško izobraževanje v Slovenski vojski - izzivi prihodnosti. V ospredje umešča razvoj vojaške stroke in znanosti, ju primerja $\mathrm{z}$ javnim izobraževalnim sistemom in opozarja na nove izzive.

Vabljeni k sodelovanju! 